\title{
COMMON AGRICULTURAL POLICY AS A DETERMINANT OF TRANSFORMATION IN POLISH AGRICULTURE
}

\author{
Daniel Rogoźnicki, Eng PhD'; Stanisław Kondracki, Full Professor²; \\ Alicja Baranowska, Eng $\mathrm{PhD}^{3}$
}

${ }^{1,3}$ Institute of Technical Sciences, Pope John Paul II State School of Higher Education in Biała Podlaska

${ }^{2}$ Department of Animal Reproduction and Hygiene, University of Natural Sciences and Humanities

\begin{abstract}
The impact assessment of the Common Agricultural Policy on transformation process of Polish agriculture following Poland's accession to European Union has been carried out. The analysis took into account the changes of the Common Agricultural Policy in terms of goals and the directions of its evolution. In the paper the alterations in land, labour and capital resources of Polish agriculture were also analysed. It has been established that funds coming from the Community budget allowed Polish agriculture to adjust to the requirement of new environment. Integration into the European Union has created good conditions to dynamic development of the agri-food sector as a whole. Acceleration of the modernization and restructuring processes of Polish farms has taken place. These developments have resulted in a reduction in the total number of farms (by $52 \%$ ) at the simultaneous rise in their average area (by $78 \%$ ). Union financial measures have also influenced on generational renewal amongst farms managers. The funds considerably enhanced farmers' incomes, which increased by $156 \%$, thus promoting expenditure on investments. As a result the improvement of technical utilities of farms has been achieved. Consequently, labour productivity growth in Polish agriculture has also been recorded. A wide range of measures within the framework of the Common Agricultural Policy enables to overcome many obstacles of the rural areas in Poland. It also creates possibilities to take advantage of naturally occurring assets in order to effectively compete on the external market.
\end{abstract}

Keywords: rural areas, Common Agricultural Policy, direct payments

\section{INTRODUCTION}

Agriculture is an important branch the national economy of Poland. In comparison to other EU Member States the share of this sector in output, employment and gross value added has been considerable for many years. The changes in the world's agri-food economy as well as the constant advance in globalization and trade liberalization have changed circumstances in Polish agriculture. According to Adamowicz (2008) 'natural, production and economic risk is a new challenge of contemporary times'. Thus, it has become necessary to enhance the pace of ongoing transformation of agriculture, and also adjust it to the rules

${ }^{1}$ Corresponding author: Sidorska 95/97, 21-500 Biała Podlaska, Poland

${ }^{2}$ Corresponding author: Prusa 14, 08-110 Siedlce, Poland, sk@uph.edu.pl

${ }^{3}$ Corresponding author: Sidorska 95/97, 21-500 Biała Podlaska, Poland 
prevailing on the European market (Mrówczyńska-Kamińska, 2013). Poland's accession to the European Union and involving its agri-food sector in the Common Agricultural Policy schemes have provided an unique opportunity for beneficial transformations in Polish agriculture and rural areas.

\section{MATERIALS AND METHODS}

The paper comprised the scale and the direction of changes in the Polish farming sector as a consequence of implementation of the Common Agricultural Policy. The rundown was based on data provided by the Ministry of Agriculture and Rural Development, the Central Statistical Office and complemented by own observations. Other sources have been used, including information and data from the literature concerning this subject. In the study, the significance of the European Agricultural Policy in the periods prior to and after Poland's accession to the European Union was taken into consideration. The impact of the Common Agricultural Policy on the direction and pace of transformation of Polish agriculture, with regard to farm size changes as well as equipping with the basic means of production, were evaluated. The analysis also accounts for alterations in the age structure of farm managers. Moreover, other changes of countryside within the concept of multifunctional sustainable development were characterized. The evolution of priorities of the Common Agricultural Policy, expressed in pre-and post-accession support schemes, was considered as a factor for the nature and intensity of transformation of rural areas in Poland.

\section{RESULTS AND DISCUSSION}

\section{Evolution of agricultural policy in Europe}

Common agricultural policy is the first and most extensive of the Community's integrated policies. Since the 1950s the main principle of Member States' policy was to prevent the crisis in the war-ravaged Europe. The farmer's income support in the form of subsidies and guaranteed prices was supposed to become an effective means of meeting food requirements of the European citizens. Additionally, the aim was to accelerate agrarian transformations (Consoli- dated versions of the Treaty..., 2008). These goals were swiftly achieved in the early 1970s.

However, a surplus of agricultural products turned out to be an adverse effect of the implementation of intervention mechanisms. The high cost of storage and maintaining minimum prices not only excessively burdened the Community budget, but also sometimes they led to destabilization of some global food markets. In response to severe criticism of conducting practices from the consumers as well as tax-payers, the liberalisation of support for agriculture and protectionism curtailment has occurred. Reductions in price support and attempts to extensify agricultural production did not counterbalance the drawbacks of ongoing actions. Impediments to diversification of economic activities, and the high fixed costs with continuously favourable financial conditions for sustaining production resulted in persistent generating of surpluses by farmers.

Finally, the turning point was the year 1991, when the so-called MacSharry reform was accepted. As a consequence, a completely new role in economy was assigned for agriculture. The adopted model of multifunctional agriculture assumed that alongside ensuring food security, pro-environmental activities will be its essential aims (Caldwell, 2004). Thus, agricultural policy of the European Union was divided into two parts. Pillar I (agriculture) concerns market policy and Pillar II (countryside) promotes rural development policy. Notably, the environmental targets are carried out for the implementation of programmes of both ones (Zegar, 2012). Following subsequent Common Agricultural Reforms led to departure from subsidising the volume and directions of agricultural production in favour of income support for farms (decoupling). The proposed regulations aimed to contribute to greater market orientation, and to focus on the realisation of the objectives of the rural development policy (OECD, 2010). The direct income support for farmers, as the single area payment was introduced. However, the granting of the aid was depended on fulfilment of standards as regards, in particular, environment, hygiene, animal welfare, food safety and product quality (cross compliance). The legal instrument, which permitted the transfer of financial resources from the first to the Pillar II of the 
agricultural policy, was also launched. The concept of sustainable development, preserving the integrity of economic, social and environmental objectives, has been strongly emphasised. (European Commission, 1999). All these activities allowed to shift the focus in conducted policy from market support towards rural areas development.

The current goals of the Common Agricultural Policy are not limited only to ensure productivity of the European agriculture, to stabilise agricultural markets and the income of agricultural producers or to supply of agricultural and food products at reasonable prices. Its multidimensional character also contains sustainable management of natural resources and the delivery of environmental public goods such as landscape, biodiversity, air, soil and water quality. The priority is the economic viability of the rural areas in any region of the European Union. It is possible to achieve through enhancing their effectiveness and economic diversity (Czyżewski and Stępień, 2013).I

\section{Influence of Common Agricultural Policy on Polish agriculture}

On 1 May 2004, Poland became a member of the European Union. Therefore, Polish agriculture began to subject to its common legal regulations. European integration has created new conditions for the development of Polish food economy. Mobilisation of Community aid schemes became a non-market tool, stimulating the desired amendments in the agricultural sectors and rural areas, The process was launched by the pre-accesion programme SAPARD (Special Accession Programme for Agriculture and Rural Development). It supported the adjustment of the Polish agri-food sector to European health and hygiene as well as environmental standards. For this purpose the beneficiaries received some PLN 4.5 billion (MRiRW, 2007). During the period 2004-2013 the total value of the aid under Common Agricultural Policy exceeded PLN 210 billion, nearly 50\% of which accounted for direct payments (Pillar I) (Wigier, 2014). These measures made a significant contribution to increasing the incomes of farms. The major part of the funds was used for covering of their current production costs such as the purchase of forage, fertilizers and plant protection products. On the contrary, pro-investment and pro- ecological activities, were financed under the Rural Development Programme (formerly the Plan) (Pillar II). They included the payments supporting socio-economic changes in rural areas in Poland, among other things, payments to areas facing natural constraints (LFAs), agri-environmental programmes or additional financial resources encouraging the development of non-agricultural activity. By the end of 2013, PLN 65 billion was paid out from the programme accounts, representing $30 \%$ of the total funding under the Common Agricultural Policy (Wigier, 2014). In the financial perspective 2014-2020 of Common Agricultural Policy EUR 28.5 billion have been earmarked, in constant prices. It is an increase of EUR 1.6 billion over the 2007-2013 budget. This follows from the greater share of expenditure on direct payments (by 37\%). The increase was achieved by means of launching the full direct payments from the budget (phasing-in). On the other hand, the significant decrease (up to $25 \%$ ) in appropriations for rural areas development took place. Consequently, it can lead to a substantial limitation of important investments related to competitiveness of farms, modernisation and entrepreneurship on rural areas in Poland (Czyżewski and Stępień, 2014).

During the several years of the Polish membership of the European Union rural areas have undergone dynamic structural and organisational changes. The necessity of competition with Western European countries, alignment to their standards and the opportunity of participating in European funds have become a strong impetus transformations in the agricultural sector. The essential reflection of the concentration of production process is an evident decrease in the overall farm numbers, while the corresponding increase in the average area has occurred. Available data show, that in the years 2002-2016 the number of farms decreased by $52 \%$ (from 2,933 to 1,410 thousand). Simultaneously, the average area of farms increased by $78 \%$ (from 5.8 to $10.3 \mathrm{ha}$ ) (GUS, 2011, 2017). These amendments were mainly caused by the decrease in the number of the smallest ones (less than $5 \mathrm{ha}$ ), which stood at around $20 \%$ at that time. The lack of properly prepared successors to the retiring owners of such farms is claimed to be the main reason for this situation. However, the amount of farms with the area exceeding 50 ha has almost doubled (Table 1). 
Proceedings of the 2018 International Scientific Conference 'Economic Sciences for Agribusiness and Rural Economy' No 1, Warsaw, 7-8 June 2018, pp. 168-174

Table 1. The changes in the area structure of farms in Poland in the years 2002, 2010 and 2016

\begin{tabular}{|l|c|c|c|c|c|c|c|}
\hline \multirow{2}{*}{$\begin{array}{l}\text { Area group } \\
\text { (ha) }\end{array}$} & \multicolumn{7}{|c|}{ Number of farms } \\
\cline { 2 - 8 } & \multicolumn{2}{|c|}{2002} & \multicolumn{2}{c|}{2010} & \multicolumn{2}{c|}{2016} & \multirow{2}{*}{$2002 / 2016$} \\
$2002=100$ \\
\cline { 2 - 8 } & thou. & $\%$ & thou. & $\%$ & thou. & $\%$ & 35.8 \\
\hline$<5$ & 2124.0 & 72.4 & 815.3 & 54 & 759.9 & 53.9 & 74.1 \\
\hline $5-20$ & 693.5 & 23.6 & 569.8 & 37.8 & 514.1 & 36.4 & 106.3 \\
\hline $20.01-50$ & 96 & 3.3 & 97 & 6.4 & 102 & 7.2 & 175.3 \\
\hline$>50$ & 19.8 & 0.7 & 27 & 1,8 & 34.7 & 2.5 & 48.1 \\
\hline Total & 2933.2 & 100 & 1509.1 & 100 & 1410.7 & 100.0 & 7 \\
\hline
\end{tabular}

Source: own elaboration based on CSO data.

This positive trend, but there is necessary to its continuation and intensification, as compared with other Member States (especially UE-15) Poland is characterized by unfavourable polarization. The slowdown of desirable changes, in this regard, is to some extent attributed to the impact of certain instruments of Common Agricultural Policy. Among these direct payments could be mentioned. The primacy of environmental goals obliging farmers to greening and diversification have the effect of reducing the scale of production (Cantore, 2013). Additionally, modulation and the degressive nature of aid are factors that restrict the land concentration process and strengthen the position of small, family farms (Czyżewski and Stępień, 2013).

In its current state the instrument perpetuates existing disparities thus reducing the benefits that follow from the improve farm business performance in Poland. The transfer of $25 \%$ of the financial envelope from the Pillar II of the Common Agricultural Policy for the years 2015-2020 to the first one, has increased the initial financial allocation for direct payments up to EUR 23.49 billion. The redistribution of a part of the additional aid for small and medium-sized farms, as a payment for the first hectares (from 3.01 to 30 ha), seems to only maintain the income level without motivation for improvement of management effectiveness. Certainly, EUR 41 per 1 ha this is insufficient to invest in the development of the activities of the new farms. Moreover, diminution of funds allocated for rural development reduces the possibility to create new non-farm jobs within rural areas. It also limits providing adequate infrastructure, favourable for stopping outmigration of young people to urban areas.

However, the increase of budget support within the Common Agricultural Policy has contributed to improved economic performance of the Polish farms. Their average annual output of the period 2004 to 2014 was PLN 72 billion (at constant 2005 prices). It was greater by $27 \%$ than in the period 1999-2003, before the accession of Poland to the European Union (Czyżewski and Stępień, 2017). At the same time, the average income of farms increased by $156 \%$ in comparison with the pre-accession period. This was notably due to the aid of European subsidies. Direct payments, on average, in the years 2004-2009 comprised $48.52 \%$ of farmers' income, whereas in the 2010-2014 period $-62.6 \%$ (IERiGŻ-PIB, 2014). Even though a certain part of this appropriation is used for consumption, it nevertheless has a positive indirect impact on the willingness to invest and the value of investment (Wigier, 2014). However, the financial support systems under the Pillar II primarily allows to increase in the pace investments in farms. The amount of support and funding received within the framework of the Pillar II of the Common Agricultural Policy has more than doubled during 2002-2014 (from PLN 2.2 to 5.2 billion). It is mainly due to the implementation of programmes such as: 'Modernisation of farms' and 'Setting-up of young farmers'. The visible result of these actions was a significant growth in investment 
outlay in the agricultural sector. This is proved by the increasing number of tractors, machinery, agricultural equipment and farm buildings put into service (Table 2). Both new and modernised buildings and fully up-to-date machinery reinforce the concept of the sustainable development, based on environmentally friendly forms of farm management.

Technological advances and progress and favourable changes in technical equipment of farms enabled Polish agriculture to increase an effectiveness of labour. This has been achieved by means of the reduction in the total labour input. The workload indicator amounted to 2,280 thousand $\mathrm{AWU}^{4}$ in 2004, while 1,937 thousand AWU in 2014 (Bear-Nawrocka and Poczta, 2016). This phenomenon appears to be closely related to labour outflows from the agricultural sector to other economic sectors and demographic alterations in rural population. The capability to adapt to changing surrounding conditions and to assimilate the effects of the latest technical development is negatively correlated with the age of Polish farmers.

The Common Agricultural Policy provides for funding mechanisms to implement measures supporting beneficial transformation of the age structure of farmers. They are aimed to enhance the generational renewal of the agricultural holders. Additional funding for setting up a farm or its modernization is available to farmers who are under years of age. On the other hand, there was a system of agricultural structural pensions which encouraged people at post-pro- ductive age to abandon production and transfer the farm to the younger one. The tangible consequence of these measures is that, in comparison with other Member States, Poland is characterised by highest the percentage of farms headed by people under 35 , namely $14.7 \%$. The average value, in this respect, throughout the European Union is $6.4 \%$. Significant decrease in the number of farms run by individuals over 65 years of age has also been recorded. In 2010 these farms represent $8.4 \%$ of the total of agricultural holdings in Poland as compared to $19.3 \%$ in 2002. They occupy $4.3 \%$ of the overall agricultural area in Poland, whereas on average in UE-15 it was three times higher (Sadowski, Baer-Nawrocka and Poczta, 2013). Thus, the impact of the Common Agricultural Policy on activation of the young and qualified persons to run a farm is clearly visible. It creates an opportunity to apply innovative solutions in the production to a greater extent, thereby contributing to improving the competitiveness of the Polish agricultural sector. Nevertheless, the measures that have been allocated to this purpose so far are not sufficient and inefficiently used. The aid has often social character impeding the process of substantial changes and solely perpetuates the status quo (Kondracki and Rogoźnicki, 2017).

The evolution of the Common Agricultural Policy is heading for further restriction of production - profitable targets. By contrast, the objectives of biodiversity, preservation and sustainability of the landscape

Table 2. Farming equipment in Polish farms in 2002, 2010 and 2016

\begin{tabular}{|l|c|c|c|c|c|}
\hline Name of machinery & 2002 & 2012 & 2016 & $\begin{array}{c}2002 / 2012 \\
2002=100\end{array}$ & $\begin{array}{c}2002 / 2016 \\
2002=100\end{array}$ \\
\hline Agricultural tractor & 1339 & 1471 & 1492 & 10.9 & 111.4 \\
\hline Combine harvesters & 123 & 152 & 160 & 12.6 & 130.1 \\
\hline & \multicolumn{5}{|c|}{ per 1 farm } \\
\hline Agricultural tractor & 0.46 & 0.65 & 1 & 141.3 & 217.4 \\
\hline Combine harvesters & 0.04 & 0.07 & 0.09 & 175.0 & 22 \\
\hline
\end{tabular}

Source: own elaboration based on CSO data.

\footnotetext{
${ }^{4}$ AWU - Annual Work Unit. In Polish agriculture 1 AWU means 2,120 hours worked per year as full time equivalent, i.e. 265 days of 8 hours per day.
} 
and unique natural resources gain in importance. This strategy is entirely consistent not only with the concept of multi-functional, but also sustainable development of rural areas. Thus, the implementation of new non-agricultural activities (i.e. production, commercial or services), which utilize country production capacity is possible. The diversification of agriculture, the development of infrastructure and local entrepreneurship may lead to economic recovery in rural areas. Thereby, the issue of employment of labour force surpluses is dealt with, as well as the adverse trend of rural depopulation is inhibited. In line with the tenets of sustainable development obtaining greater economic performances may not cause any negative repercussions on the natural living environment. It should be noted that a pro-environmental character of the Common Agricultural Policy is supported both under Pillars I and II. In its current state $30 \%$ of the financial envelope for direct payments (Pillar I) constitutes 'greening'. In order to receive it, the farms over 15 ha of arable land have to exclude at least $5 \%$ of it for 'ecological focus areas' (EFA). Moreover, in the case of the farms over 10 ha of arable land the crop diversification is compulsory. The payments degressivity concerns farms with the greatest area.

Beneficiaries of the Pillar II of the Common Agricultural Policy, who expenditure carry out the obligations under agri-environmental-climatic programmes, decide on abandonment of intensive agricultural production. It implies a decrease in economic efficiency of their farms. However, additional financial resources are a strong incentive for altering management practices in agriculture towards reducing its adverse impact on environment. Besides, the foregone income may be compensated. As a result, the tendency of significant increase in the total agricultural area subjected to agri-environment payments in Poland has been noticed. In 2013 it amounted to $2,614,808$ ha, accounting for $13 \%$ of the overall the agricultural area in Poland. In comparison with 2006 $(889,842 \mathrm{ha})$ this figure has almost tripled. According to the categorisation of support under the Common Agricultural Policy for the years 2007-2013 organic farming is treated as a separate measure. So far, it has been a component of agri-environment package. It emphasizes of its gaining importance. In 2004-2014 the number of certified organic farms in Poland has increased almost seven-fold (3,760 and 25,427, respectively). During the same period the areas under organic farming have expanded eight-fold (IJHARS, 2015). Favourable environmental conditions ensure that Polish organic farming creates a greater opportunity to compete on the international market than the conventional one. Relatively large manual labour input is an important factor affecting the growth in employment and the increase of income levels of local inhabitants. As a result, organic farming may become a key stimulus for the local labour market, preventing the migration process. This might lead to boost the local and regional development in the longer term.

\section{CONCLUSIONS}

Following Poland's accession the European Union, numerous structural changes have been carried out in Polish agriculture. Although, it is still undergoing significant transformations. The progressing process of adaptation aims at strengthening the competitiveness of Polish agriculture, has also revealed its serious weaknesses. The fragmented agrarian structure, technical and technological delays as well as the extensive nature of production are barriers that impede the effective competition of Polish farms with the European ones. The measures under the Common Agricultural Policy constitute a tangible support of the Polish agricultural changes. The financial support of the European budget for the current financing period (i.e. 2014-2020) is smaller than previous ones. Nevertheless, without such wherewithal the development of Polish agriculture and rural areas would be much more difficult. The determination of new priorities and purposes of the Common Agricultural Policy in the next financial perspective after 2020 require a continuous assessment of the achievements made so far.

\section{REFERENCES}

1. Adamowicz, M. (2008). Ewolucja Wspólnej Polityki Rolnej Unii Europejskiej i jej perspektywy na drugą dekade XXI wieku [The evolution of the Common Agricultural Policy of the European Union and its prospects 
for the second decade of the 21st century]. In: Kopycińska, D. (ed.) Polityka Unii Europejskiej [European Union policy]. PRINT GROUP Daniel Krzanowski, Szczecin.

2. Bear-Nawrocka, A., Poczta, W. (2016). Polskie rolnictwo na tle Unii Europejskiej [Polish agriculture against the background of the European Union]. In: Wilkin, J., Nurzyńska, I. (eds.) Polska wieś 2016. Raport o stanie wsi [Polish village 2016. Report on the state of the village]. Wydawnictwo Naukowe Scholar, Warszawa, pp. 85-98.

3. Cantore, N., (2013). The potential impact of a greener CAP on developing countries. Overseas Development Institute, London.

4. Cardwell, M. (2004). The European Model of Agriculture. Oxford University Press, Oxford.

5. Consolidated versions of the Treaty on European Union and the Treaty on the Functioning of the European Union. OJ C115 of 09.05.2008.

6. Czyżewski, A., Stępień, S. (2013). Ekonomiczno-społeczne uwarunkowania zmian paradygmatu rozwoju rolnictwa drobnotowarowego w świetle ewolucji wspólnej polityki rolnej [Economic and social conditions of changes in the paradigm of the development of small-scale agriculture in the light of the evolution of the common agricultural policy]. Problemy Drobnych Gospodarstw Rolnych, 2, pp. 25-39.

7. Czyżewski, A., Stępień, S. (2014). Fundusze unijne dla Polski i polskiego sektora rolnego w perspektywie 2014-2020 [EU funds for Poland and the Polish agricultural sector in the 2014-202 perspective]. Polityki Europejskie, Finanse i Marketing, 11 (60), pp. 34-45.

8. Czyżewski, A., Stępień, S. (2017). Rozwój obszarów wiejskich w warunkach funkcjonowania WPR jako stymulanta zmian strukturalnych w polskim rolnictwie. Integracja europejska jako determinanta polityki wiejskiej aspekty ekonomiczne [Development of rural areas in the conditions of the CAP functioning as a stimulant of structural changes in Polish agriculture. European integration as a determinant of rural policy economic aspects]. FAPA, Warszawa, pp. 37-54.

9. European Commission (1999). Communications from the Commission to the Council; the European Parliament; the Economic and Social committee and the Committee of the Regions. Directions towards sustainable agriculture. COM (1999) final of 27.01.1999.
10. GUS (2011). Raport z wyników. Powszechny spis rolny 2010 r. [Report on results. Universal agricultural census 2010]. Dział Wydawnictw Statystycznych GUS, Warszawa.

11. GUS (2017). Użytkowanie gruntów i powierzchnia zasiewów w 2016 r. [Land use and sown area in 2016]. Dział Wydawnictw Statystycznych GUS, Warszawa.

12. IERiGŻ-PIB (2014). Wyniki standardowe polskiego FADN 2014 [Standard results of the Polish FADN 2014]. Warszawa.

13. IJHARS (2015). Raport o stanie rolnictwa ekologicznego w Polsce w latach 2013-2014 [Report on the state of organic farming in Poland in 2013-2014]. Warszawa.

14. Kondracki, S., Rogoźnicki, D. (2017). Plan i Program Rozwoju Obszarów Wiejskich jako czynniki przekształceń polskiego rolnictwa po akcesji do Unii Europejskiej. Integracja europejska jako determinanta polityki wiejskiej, Aspekty ekonomiczne [Plan and Programme for Agriculture and Rural Development as factors for the transformation of Polish agriculture after accession to the European Union. European integration as a determinant of rural policy, economic aspects]. FAPA, Warszawa, pp. 107-135.

15. MRiRW (2007). Informacja o rezultatach Programu SAPARD [Information on the results of the SAPARD Programme]. Warszawa.

16. Mrówczyńska-Kamińska, A. (2013). Znaczenie agrobiznesu w gospodarce narodowej w krajach Unii Europejskiej [Importance of agribusiness in the national economy in the European Union countries]. Gospodarka Narodowa, 3 (259), pp. 79-100.

17. OECD (2010). Evaluation of agricultural policy reforms in the European Union. Draft Report. Paris.

18. Sadowski, A., Baer-Nawrocka, A., Poczta, W. (2013). Gospodarstwa rolne w Polsce na tle gospodarstw Unii Europejskiej - wpływ WPR. Powszechny spis rolny 2010 [Agricultural holdings in Poland against the background of EU farms - the impact of the CAP. Universal agricultural census 2010]. Dział Wydawnictw Statystycznych GUS, Warszawa.

19. Wigier, M. (2014). Changes in the Polish agriculture in the light of the CAP implementation. Zagadnienia Ekonomiki Rolnej, 4, pp. 50-66.

20. Zegar, J.S. (2012). Współczesne wyzwania rolnictwa [Contemporary agriculture challenges]. Wydawnictwo Naukowe PWN, Warszawa. 